\title{
Redefining cost-optimal nZEB levels for new residential buildings
}

\author{
Raimo Simson ${ }^{1, *}$, Endrik Arumägi ${ }^{1}$, Kalle Kuusk ${ }^{1}$ and Jarek Kurnitski ${ }^{1,2}$ \\ ${ }^{1}$ Tallinn University of Technology, Department of Civil Engineering and Architecture, Ehitajate tee 5, Tallinn, Estonia \\ ${ }^{2}$ Aalto University, School of Engineering, Otakaari 4, Espoo, Finland
}

\begin{abstract}
In the member states of the European Union (EU), nearly-Zero Energy Buildings (nZEB) are becoming mandatory building practice in 2021. It is stated, that nZEB should be cost-optimal and the energy performance levels should be re-defined after every five years. We conducted cost-optimality analyses for two detached houses, one terraced house and one apartment building in Estonia. The analysis consisted on actual construction cost data collection based on bids of variable solutions for building envelope, air tightness, windows, heat supply systems and local renewable energy production options. For energy performance analysis we used dynamic simulation software IDA-ICE. To assess cost-effectiveness, we used Net Present Value (NPV) calculations with the assessment period of 30 years. The results for cost-optimal energy performance level for detached house with heated space of $\sim 100 \mathrm{~m}^{2}$ was $79 \mathrm{kWh} /\left(\mathrm{m}^{2}\right.$ a), for the larger house $\left(\sim 200 \mathrm{~m}^{2}\right) 87 \mathrm{kWh} /\left(\mathrm{m}^{2} \mathrm{a}\right)$, for terraced house with heated space of $\sim 600 \mathrm{~m}^{2} 71 \mathrm{kWh} /\left(\mathrm{m}^{2}\right.$ a) and for the apartment building $103 \mathrm{kWh} /\left(\mathrm{m}^{2}\right.$ a) of primary energy including all energy use with domestic appliances. Thus, the decrease in cost-optimal level in a five-year period was $\sim 60 \%$ for the detached house and $\sim 40 \%$ for the apartment building, corresponding to a shift in two EPC classes.
\end{abstract}

\section{Introduction}

In the European Union, Energy Performance of Buildings Directive 2010/31/EU (EPBD) [1] obligates Member States (MS) to assure that minimum energy performance requirements for buildings are set to achieve cost-optimal levels. As of 2021, the minimum requirement for all new and significantly renovated buildings in the $\mathrm{EU}$ is the nZEB level [2]. The directive [1] describes nZEB as a building with very high energy performance. The low amount of energy required to 'run' the building should be covered mostly by energy from on-site renewable sources such as photovoltaic solar panels (PV-panels).

The cost-optimal level is defined as "the energy performance level which leads to the lowest cost during the estimated economic lifecycle" [1] from two different perspectives: financial (looking at the investment itself at the building level) and macro-economic (looking at the costs and benefits of energy efficiency for society as a whole). It is stated, that MS should take necessary measures to ensure that minimum requirements for energy performance are set for building elements that have a significant impact on the energy performance of the building when they are replaced or retrofitted, with a view to achieving cost-optimal levels. The analysis needs to include best available technical solutions and therefore enable the assessment of nZEB performance levels and cost implications with very little extra effort [3].
The first cost-optimal levels in Estonia were calculated in 2011 [4]. As a major change in the electricity primary energy factor, the calculations were updated in 2013 [3] and enforced by national regulation. After the initial implementation, a study conducted in 2015 by Pikas et al. [5] reported that since then the cost-optimal level for apartment buildings shifted from $145 \mathrm{kWh} /\left(\mathrm{m}^{2} \mathrm{a}\right)$ to $110 \mathrm{kWh} /\left(\mathrm{m}^{2} \mathrm{a}\right)$, i.e. from Energy Performance Certificate (EPC) class $\mathrm{C}$ to $\mathrm{B}$. However, achieving nZEB level (class A) of $100 \mathrm{kWh} /\left(\mathrm{m}^{2} \mathrm{a}\right)$ was still found to require relatively high additional investments. The cost-optimal levels for detached house at in 2013 were found to be 140 $\mathrm{kWh} /\left(\mathrm{m}^{2} \mathrm{a}\right)$ with ground source heat pump and 160 $\mathrm{kWh} /\left(\mathrm{m}^{2} \mathrm{a}\right)$ with gas boiler and the nZEB level defined as $50 \mathrm{kWh} /\left(\mathrm{m}^{2} \mathrm{a}\right)$.

In 2014, Kurnitski et al. found that cost-optimal level of deep integrated renovation corresponded in most cases to minimum energy performance requirements of new residential buildings [6]. More recent calculations by Kuusk and Kalamees [7] in 2016 showed a similar shift of one EPC class (from C to B) as with new apartment buildings.

In this paper we analysed the financial and macroeconomic perspective of the cost-efficiency of building energy performance related solutions. We performed calculations of cost-optimal energy performance levels for new residential buildings and compared the results with data from previous calculations.

* Corresponding author: raimo.simson@taltech.ee 


\section{Methods}

The energy demand of a building was calculated according to the methodology for calculating the energy efficiency of buildings [8], using dynamic energy simulation software IDA Indoor Climate and Energy 4.7.1 (IDA-ICE) [9]. The software used for calculations meets all the software requirements in the regulation on minimum energy performance requirements [10]. The results obtained from the dynamic simulations were used to assess the energy savings potential of different energy efficiency measures and to calculate the energy consumption of buildings with varying technical and building envelope specific solutions.

The unit prices required for calculating the additional cost of various structural solutions affecting the energy use of buildings were obtained from construction companies by the building type. The budget officers provided unit costs per square metre for various structural solutions, windows, openings and other building envelope elements, which also included the costs of material and installation. The costs of solar panels were estimated. The costs of structures, openings and technical systems were calculated by the companies. All calculated costs included value-added tax (VAT).

\subsection{Energy calculations}

A room-based simulation model was developed for all buildings. The models were designed according to the architectural bases, views and sections of buildings. The solutions for openings and the building envelope were selected according to the building design.

First of all, simulation models were developed to assess the impact of individual components of the building envelope on the energy consumption of the building. In the initial energy simulations, only one component was changed and the result was compared to the energy consumption of the original building. The variable of the individual modifiable components was the thermal transmittance of the relevant component. In addition to the thermal transmittance, the effect of the building's air permeability was also assessed. The values of thermal transmittance $(U)$ and air leakage $\left(q_{50}\right)$ of different structural solutions used in simulation models were as follows:

- $U$ of the external wall $\left[\mathrm{W} /\left(\mathrm{m}^{2} \cdot \mathrm{K}\right)\right]: 0.16,0.14$, $0.12,0.10$;

- $U$ of the roofing $\operatorname{deck}\left[\mathrm{W} /\left(\mathrm{m}^{2} \cdot \mathrm{K}\right)\right]: 0.12,0.10$, 0.08 ;

- $\quad U$ of the floor $\left[\mathrm{W} /\left(\mathrm{m}^{2} \cdot \mathrm{K}\right)\right]: 0.18,0.14,0.10$;

- $\quad U$ of the windows $\left[\mathrm{W} /\left(\mathrm{m}^{2} \cdot \mathrm{K}\right)\right]: 1.1,0.9,0.7$;

- $\quad$ value of $\mathrm{q}_{50}\left[\mathrm{~m}^{3} /\left(\mathrm{h} \cdot \mathrm{m}^{2}\right)\right]: 6.0,3.0,1.5$, and 1.0.

In addition to assessing the impact of the individual components on the building's energy consumption, the calculation of the energy efficiency indicator was performed for all combinations by combining various values of thermal conductivity and air leakage of structural solutions.
The Energy Performance Indicator (EPI) values were calculated from building energy consumption calculation results using primary energy weighting factors for different energy carriers according to the Estonian Regulation No 58 'Methodology for calculating the energy performance of buildings' [8]:

1) wood-based fuels and other biofuels 0.75 ;

2) district heating 0.9;

3) liquid fuels, natural gas and solid fossil fuels 1.0;

7) electricity 2.0 .

\subsection{Cost-effectiveness calculations}

The financial calculations are based on the methodology described in Delegated Regulation (EU) No 244/2012 of the European Commission [2].

The cost-effectiveness of different structural solutions was estimated using the net present value method:

$$
\left.C_{G(\tau)}=C_{i}+\sum_{i=1}^{\tau}\left(C_{a, i}\right) \cdot R_{d}(i)\right)
$$

where:

$\tau$ is the calculation period;

$\mathrm{C}_{\mathrm{G}(\tau)}$ is the total cost (referred to starting year $\tau_{0}$ ) over the calculation period;

$\mathrm{C}_{\mathrm{i}}$ is the initial investment costs for measure or set of measures $\mathrm{j}$;

$\mathrm{C}_{\mathrm{a}, \mathrm{i}(\mathrm{j})}$ is the annual cost during year $\mathrm{i}$ for measure or set of measures $\mathrm{j}$;

$R_{d}(i)$ means discount factor for year $i$.

The cost effectiveness of the additional costs related to structural solutions and renewable energy solutions that were needed to meet the requirements of nZEB was assessed with the following equation:

$$
\Delta \mathrm{NPV}=\left(C_{G}^{n Z E B}-C_{G}^{r e f}\right) / A_{\text {floor }}
$$

The discount was calculated using the calculated interest rate and a relative price increase during the calculation period. The cost-effectiveness calculation period was chosen to be 30 years. The discount was based on the real interest rate of $2.5 \%$, which corresponds to the rate of return of $3.5 \%$ when inflation is $1 \%$. The real escalation of energy prices for the calculation period was taken at 1 $\%$ per annum (Table 1 ).

The initial purchase price of energy carriers was calculated at the following prices (including VAT):

- $\quad$ electricity purchase $0.113 \mathrm{EUR} / \mathrm{kWh}$;

- electricity sale $0.035 \mathrm{EUR} / \mathrm{kWh}$ (re-sale price of electricity from PV panels back to the network);

- district heating $0.060 \mathrm{EUR} / \mathrm{kWh}$;

- natural gas $0.048 \mathrm{EUR} / \mathrm{kWh}$;

- wood pellet $0.045 \mathrm{EUR} / \mathrm{kWh}$. 
Financial calculations were based on the additional investment needed to achieve the nZEB levels. When calculating the additional cost of the measure/package, the prices payable by the customer, including all applicable taxes, VAT and support were taken into account in the financial calculations. The calculations did not take into account the potential support that may apply to the introduction of various technologies related to the production of renewable energy.

The cost of building components was calculated by totalling the different expense types and by applying a discount rate to them using the discount factor.

The criterion of profitability is that the net revenue generated and discounted during the economic life of the investment should be greater than the initial investment.

Table 1. Parameter values used for discount.

\begin{tabular}{|c|c|}
\hline Name & Value \\
\hline $\begin{array}{c}\text { Thermal energy price, (district } \\
\text { heating) EUR/kWh }\end{array}$ & 0.05995 \\
\hline $\begin{array}{c}\text { Thermal energy price, (gas) } \\
\text { EUR/kWh }\end{array}$ & 0.04774 \\
\hline Electricity price, EUR/kWh & 0.11316 \\
\hline $\begin{array}{c}\text { Electricity price, when sold to the } \\
\text { grid EUR/kWh }\end{array}$ & 0.035 \\
\hline $\begin{array}{c}\text { Real interest rate, } \% \\
\text { Escalation (electricity), } \%\end{array}$ & 1 \\
\hline $\begin{array}{c}\text { Escalation (thermal energy), } \% \\
\text { Calculation period for residential } \\
\text { buildings, years }\end{array}$ & 30 \\
\hline
\end{tabular}

The macroeconomic calculations are based on the methodology described in Delegated Regulation (EU) No 244/2012 of the European Commission. The total cost of the measures is calculated as follows:

$$
\left.C_{G(\tau)}=C_{i}+\sum_{j}\left[\sum_{i=1}^{\tau}\left(C_{a, i}\right) \cdot R_{d}(i)+C_{c, i}(j)\right)\right]
$$

where:

$\tau$ means the calculation period;

$\mathrm{CG}_{(\tau)}$ means total cost (referred to starting year $\tau_{0}$ ) over the calculation period;

$\mathrm{C}_{\mathrm{i}}$ means initial investment costs for measure or set of measures $\mathrm{j}$;

$\mathrm{C}_{\mathrm{a}, \mathrm{i}(\mathrm{j})}$ means annual cost during year $\mathrm{i}$ for measure or set of measures $\mathrm{j}$;

$\operatorname{Rd}_{(i)}$ means discount factor for year $\mathrm{i}$;

$\mathrm{C}_{\mathrm{c}, \mathrm{i}}(\mathrm{j})$ means annual cost of $\mathrm{CO}_{2}$ emissions during year $\mathrm{i}$ for measure or set of measures $\mathrm{j}$.

The calculations are based on the prognosis of the longterm $\mathrm{CO}_{2}$ price variation in the Delegated Regulation (EU) No 244/2012 of the European Commission.
Calculations of the amounts of $\mathrm{CO}_{2}$ emissions required for macroeconomic calculations are based on the $\mathrm{CO}_{2}$ specific emission rates provided in the report 'Study on the cost-effective minimum energy efficiency requirements for buildings. Weighting factors for energy carriers'.

The $\mathrm{CO}_{2}$ specific emission factors for the main energy carriers calculated in the report 'Study on the costeffective minimum energy efficiency requirements for buildings. Weighting factors for energy carriers' are given in Table 2.

Table 2. $\mathrm{CO}_{2}$ specific emission factors for the energy carriers.

\begin{tabular}{|c|c|}
\hline Energy carrier & $\begin{array}{c}\mathbf{C O}_{2} \text { specific emissions } \\
\text { kgCO} / \mathbf{M W h}\end{array}$ \\
\hline Electricity & 1150 \\
\hline District heating & 193 \\
\hline $\begin{array}{c}\text { Efficient district heating } \\
\text { Extremely efficient } \\
\text { district heating }\end{array}$ & 39 \\
\hline Gas & 39 \\
\hline
\end{tabular}

\subsection{Description of the buildings}

For the calculations four sample residential buildings were selected. The characteristic parameters of the analysed buildings are presented in Table 3 . The small house is a single-storey building with rectangular floor plan. The load-bearing part of the building is a wooden structure. The external walls of the building are insulated timber frame walls covered externally with boards, while the internal walls are timber framing walls covered with plasterboard.

Detached house has two floors with rectangular floor plan. The bearing part of the building is a stone structure with ceiling slabs of reinforced concrete elements. The external walls of the building are externally insulated concrete block walls.

Terraced building has two floors. The building is divided into six sections with separate entrances. It has a rectangular base plan with some protruding parts on the façade. External walls of the building are made of wall elements on a wooden frame, and these are covered with plasterboard on the inside.

Selected apartment building is a 5-storey apartment block with underground parking. This building has a Ushaped floor plan. The building has a 5-storey main section and 3- or 4-storey wings. There is an enclosed parking area under the building and additional parking spaces located under the projecting parts of the building facing the courtyard. The building has a concrete bearing structure with stone and concrete walls. 
Table 3. Technical characteristics of the buildings.

\begin{tabular}{|c|c|c|c|c|}
\hline Parameter & $\begin{array}{c}\text { Small } \\
\text { house }\end{array}$ & $\begin{array}{c}\text { Detached } \\
\text { house }\end{array}$ & $\begin{array}{c}\text { Terraced } \\
\text { house }\end{array}$ & $\begin{array}{c}\text { Apartment } \\
\text { building }\end{array}$ \\
\hline $\begin{array}{c}\text { Heated } \\
\left.\text { area (m }{ }^{2}\right)\end{array}$ & 101 & 206 & 676.8 & 6373 \\
\hline $\begin{array}{c}\text { Base area } \\
\text { of the } \\
\text { building } \\
\left.\text { (m }^{2}\right)\end{array}$ & 167 & 179 & 643.4 & 1618 \\
\hline $\begin{array}{c}\text { Floors } \\
\text { above the } \\
\text { ground }\end{array}$ & 1 & 2 & 2 & 5 \\
\hline $\begin{array}{c}\text { Floors } \\
\text { below the } \\
\text { ground }\end{array}$ & - & - & - & 1 \\
\hline Height (m) & 6.7 & 7 & 6.6 & 17.8 \\
\hline Length (m) & 14.2 & 19.9 & 53.2 & 54.3 \\
\hline Width (m) & 9.6 & 12.8 & 22.9 & 35.7 \\
\hline $\begin{array}{c}\text { Closed net } \\
\left.\text { area (m }{ }^{2}\right)\end{array}$ & 101.1 & 190.3 & 676.8 & 6373 \\
\hline $\begin{array}{c}\text { Capacity } \\
\left(\mathrm{m}^{3}\right)\end{array}$ & 400 & 1252 & 2180 & 25900 \\
\hline $\begin{array}{c}\text { Common } \\
\left.\text { area (m }{ }^{2}\right)\end{array}$ & 4 & 4 & 6 & 2009.2 \\
\hline $\begin{array}{c}\text { Dwelling } \\
\left.\text { area (m }{ }^{2}\right)\end{array}$ & 79.1 & 160.8 & 676.8 & 3713.8 \\
\hline $\begin{array}{c}\text { Total } \\
\text { dwelling } \\
\text { rooms }\end{array}$ & 4 & 16 & 51 \\
\hline
\end{tabular}

\subsection{Building envelope solutions cost}

The costs of the structural solutions for private residential buildings and apartment blocks based on the bids were received from builders. Example of the price deviation are shown in the following graphs (Figures 1-4). The estimated cost of the structures is presented depending on the thermal transmittance. In case of detached houses and terraced house, only timber frame walls were accounted. In contrast, for apartment building calculations only concrete block and reinforced concrete wall solutions were used.

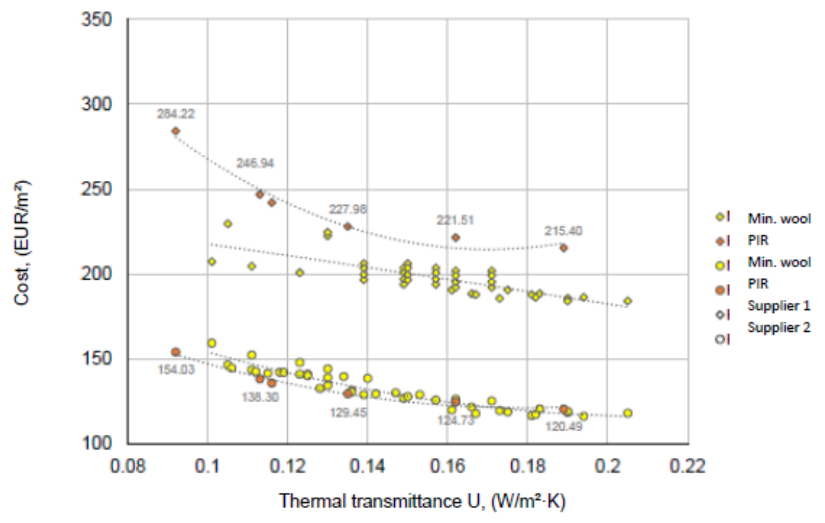

Fig. 1. Cost of timber frame walls with different insulation.

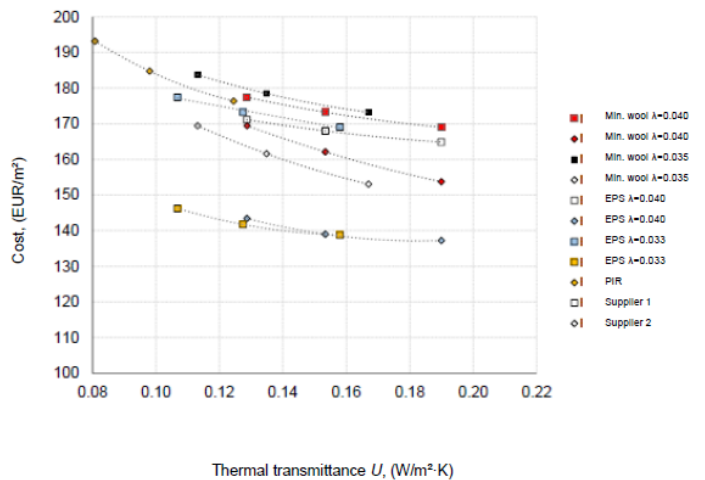

Fig. 2. Cost of concrete block walls with rendering.

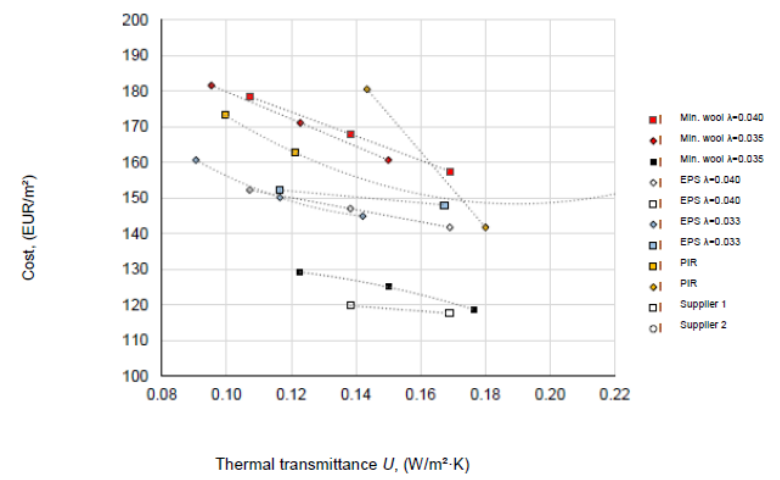

Fig. 3. Cost of reinforced concrete walls with different insulation.

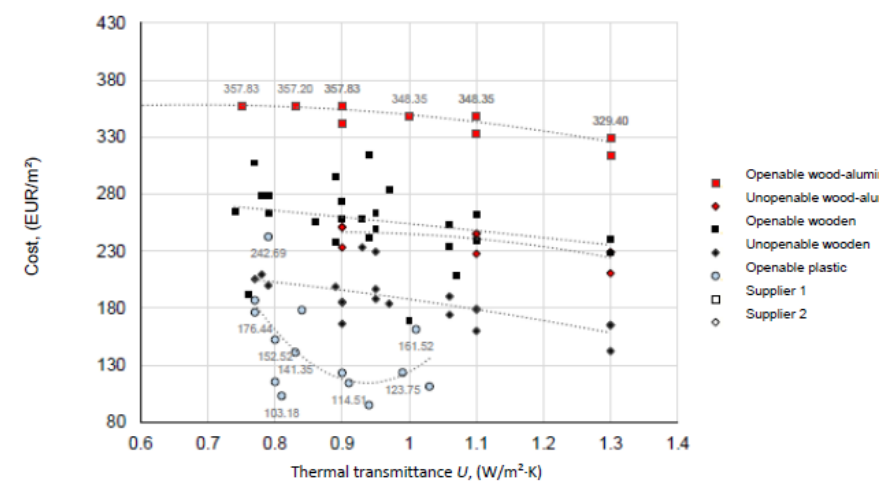

Fig. 4. Cost of windows.

\section{Results}

The simulations and calculations for assessing the costeffectiveness of technical solutions are based on the selected four sample buildings.

Figures 5-7 show the results of cost-effectiveness calculations for the detached houses and terraced building with different combinations of structural solutions and heat sources.

In the case of a smaller detached house, the costoptimal range of Energy performance indicator (EPI) without local production of renewable energy is between 123 and $131 \mathrm{kWh} /\left(\mathrm{m}^{2} \mathrm{a}\right)$, and the additional investment is in the range between 7.4 and 16.9 EUR/ $\mathrm{m}^{2}$ (Figure 5). In the case of a detached residential building $\left(200 \mathrm{~m}^{2}\right)$, the cost-optimal range of EPI without local production of renewable energy is between 137 and $141 \mathrm{kWh} /\left(\mathrm{m}^{2} \mathrm{a}\right)$, and the additional investment is in the range between 13.6 and 
17.1 EUR $/ \mathrm{m}^{2}$ (Figure 6). In the case of the terraced building, the cost-optimal range of EPI without local production of renewable energy is between 84 and 86 $\mathrm{kWh} /\left(\mathrm{m}^{2} \mathrm{a}\right)$, and the additional investment is in the range between 22.7 and 31.4 EUR/m² (Figure 7). Without local renewable energy production, the cost-optimal range of EPI for an apartment block is approximately from 115 to $117 \mathrm{kWh} /\left(\mathrm{m}^{2} \mathrm{a}\right)$, and the additional investment is between 6.2 and $9.6 \mathrm{EUR} / \mathrm{m}^{2}$ (Figure 8).

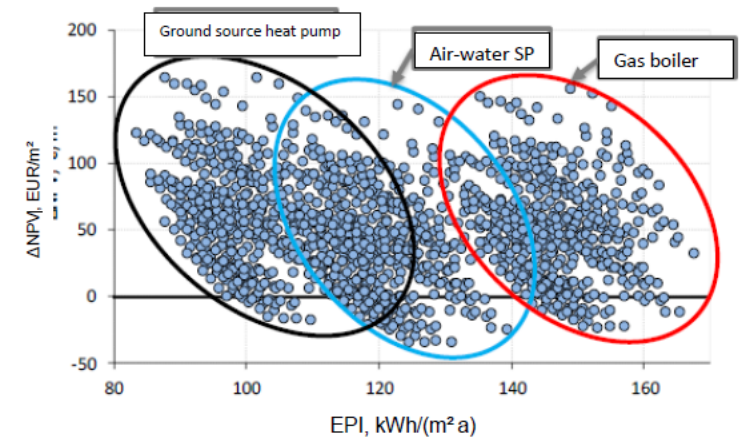

Fig. 5. Energy performance indicator (EPI) of a detached residential building $\left(100 \mathrm{~m}^{2}\right)$ and change in the net present value $(\triangle \mathrm{NPV})$ for different combinations of structural solutions and heat sources.

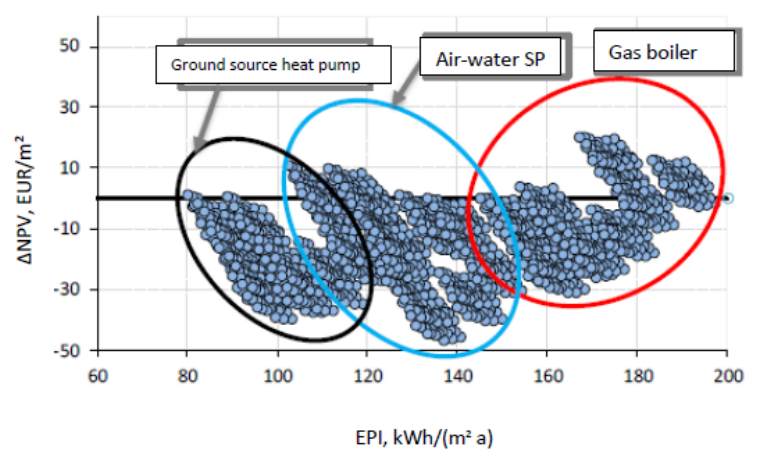

Fig. 6. Energy performance indicator (EPI) of a detached residential building $\left(200 \mathrm{~m}^{2}\right)$ and change in the net present value $(\triangle \mathrm{NPV})$ for different combinations of structural solutions and heat sources.

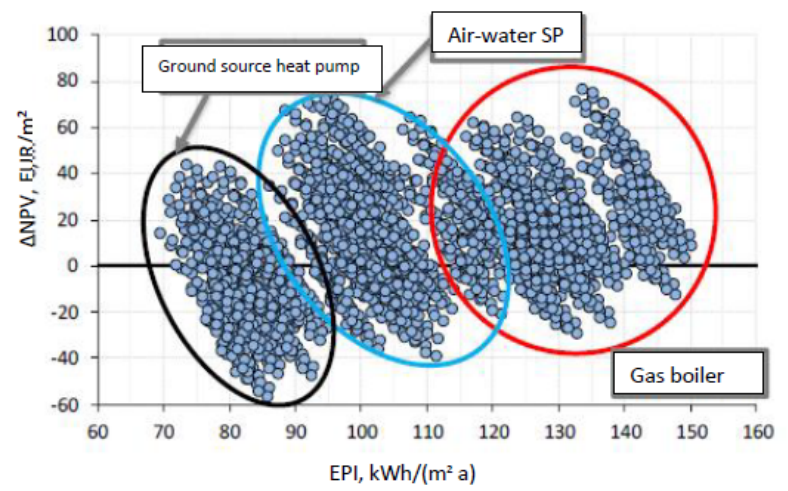

Fig. 7. Energy performance indicator (EPI) of a terraced building and change in the net present value $(\triangle \mathrm{NPV})$ for different combinations of structural solutions and heat sources.

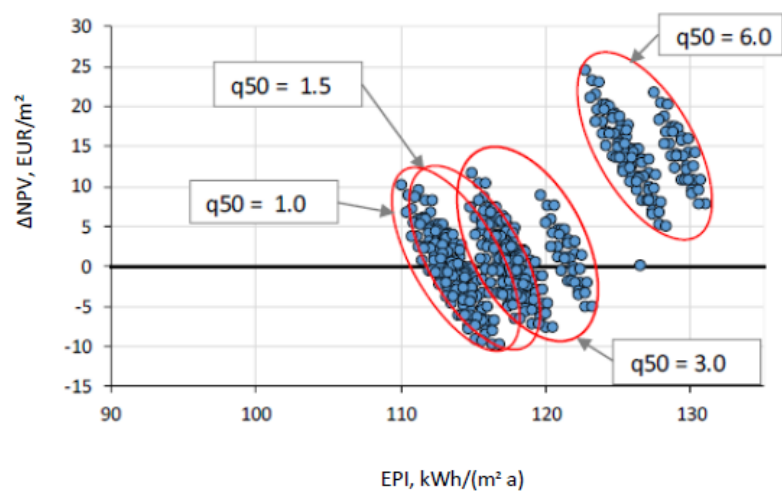

Fig. 8. Energy performance indicator (EPI) of an apartment block and change in the net present value $(\triangle \mathrm{NPV})$ for different combinations of structural solutions and building air tightness.

Based on the definition of nZEB given in the EPBD, local production of renewable energy is required to reach the nearly zero-energy level. Local generation of renewable energy is added below to the architecturally and technically appropriate combinations. Electricity generation with solar panels was considered as a solution for local production of renewable energy. Figures 9-12 show the results of cost-effectiveness calculations for residential buildings in different combinations of structural solutions, heat sources and local renewable energy production with $\mathrm{PV}$ panels.

According to the current requirements in Estonia, the limit value of the nearly zero-energy level for a residential building is the EPI of $\leq 50 \mathrm{kWh} /\left(\mathrm{m}^{2} \mathrm{a}\right)$. The results of the calculations show that the cost-optimal levels of EPI for selected buildings exceed the current nearly zero-energy limit value. With local renewable energy production, the cost-optimal range of EPI for a detached residential building $\left(100 \mathrm{~m}^{2}\right)$ is from 77 to $83 \mathrm{kWh} /\left(\mathrm{m}^{2} \mathrm{a}\right)$, and the additional investment is between 51.0 and $58.3 \mathrm{EUR} / \mathrm{m}^{2}$ (Figure 9).

With local renewable energy production, the costoptimal range of EPI for a detached residential building $\left(200 \mathrm{~m}^{2}\right)$ is from 87 to $91 \mathrm{kWh} /\left(\mathrm{m}^{2} \mathrm{a}\right)$, and the additional investment is between 63.2 and $66.7 \mathrm{EUR} / \mathrm{m}^{2}$ (Figure 10).

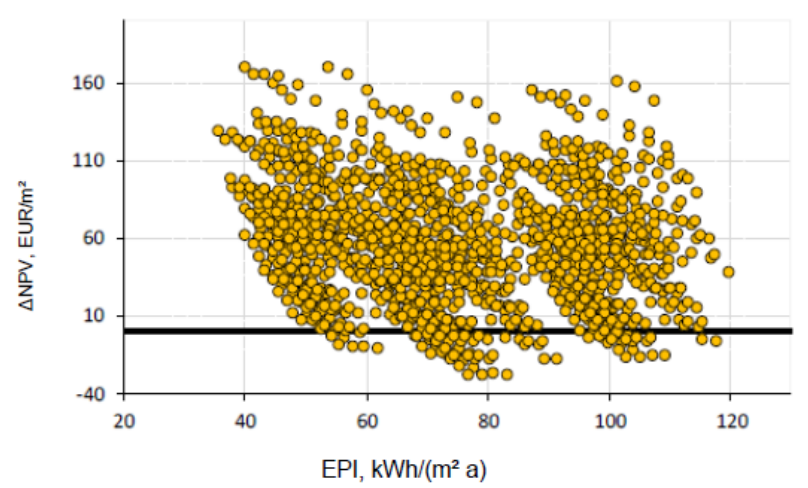

Fig. 9. Energy performance indicator (EPI) of a detached residential building $\left(100 \mathrm{~m}^{2}\right)$ and change in the net present value $(\triangle \mathrm{NPV})$ for different combinations of structural solutions and heat sources with local renewable energy production (PV panels with a nominal power of $2.8 \mathrm{~kW}$ ). 


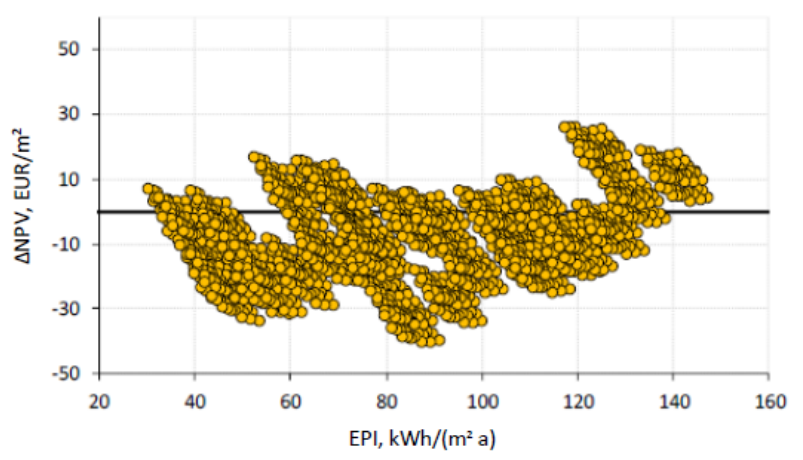

Fig. 10. Energy performance indicator (EPI) of a detached residential building $\left(200 \mathrm{~m}^{2}\right)$ and change in the net present value $(\triangle \mathrm{NPV})$ for different combinations of structural solutions and heat sources with local renewable energy production (PV panels with a nominal power of $4.0 \mathrm{~kW}$ ).

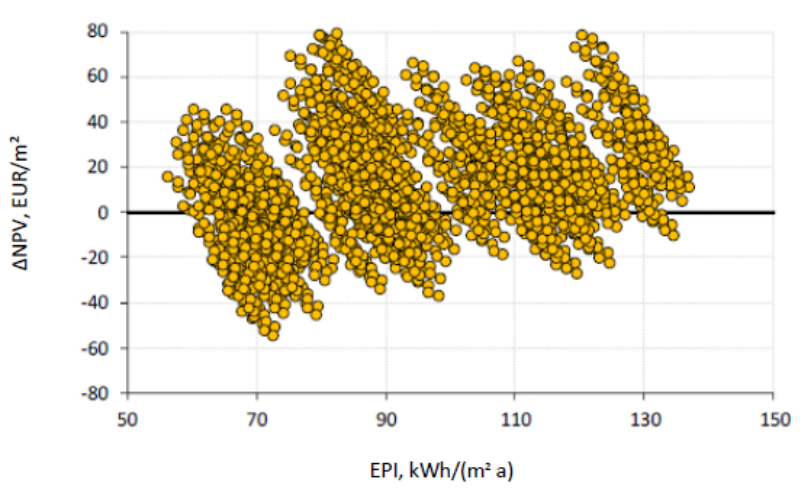

Fig. 11. Energy performance indicator (EPI) of a terraced building and change in the net present value ( $\triangle \mathrm{NPV}$ ) for different combinations of structural solutions and heat sources with local renewable energy production (PV panels with a nominal power of $4.5 \mathrm{~kW}$ ).

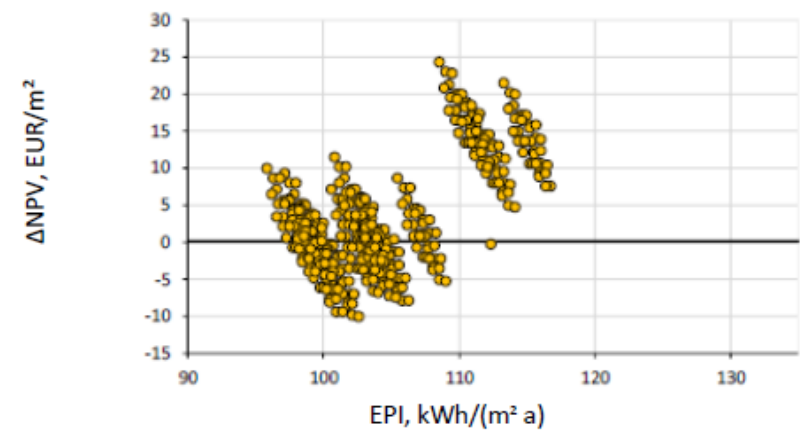

Fig. 12. Energy performance indicator (EPI) of an apartment block and change in the net present value ( $\triangle \mathrm{NPV}$ ) for different combinations of structural solutions and heat sources with local renewable energy production (PV panels with a nominal power of $53 \mathrm{~kW}$ ).

With local renewable energy production, the cost-optimal range of EPI for a terraced building is from 71 to 73 $\mathrm{kWh} /\left(\mathrm{m}^{2} \mathrm{a}\right)$, and the additional investment is between 35.9 and 44.6 EUR/m² (Figure 11).

According to the current Estonian requirements, the limit value of the nearly zero-energy level for a section of an apartment block is an EPI of $\leq 100 \mathrm{kWh} /\left(\mathrm{m}^{2} \mathrm{a}\right)$. The results of the calculations show that the cost-optimal levels of EPI exceed the current nearly zero-energy limit value.

With local renewable energy production, the costoptimal range of EPI for an apartment block is from 101 to $103 \mathrm{kWh} /\left(\mathrm{m}^{2} \mathrm{a}\right)$, and the additional investment is between 22.9 and $26.3 \mathrm{EUR} / \mathrm{m}^{2}$ (Figure 12).

Figures 13-15 show the macroeconomic calculation results for the detached houses and the apartment building. At the macroeconomic level, the cost-optimal range of EPI for the $100 \mathrm{~m}^{2}$ detached house with a groundsource heat-pump and PV-panels is 60 to $70 \mathrm{kWh} /\left(\mathrm{m}^{2} \mathrm{a}\right)$ (Figure 13). In case of gas boiler, the values are between 115 and $119 \mathrm{kWh} /\left(\mathrm{m}^{2} \mathrm{a}\right)$ (Figure 12). The $200 \mathrm{~m}^{2}$ detached house performs better resulting in cost-optimal EPI range of 55 to $65 \mathrm{kWh} /\left(\mathrm{m}^{2} \mathrm{a}\right)$ with GSHP and PV-panels; between 115 and $119 \mathrm{kWh} /\left(\mathrm{m}^{2} \mathrm{a}\right)$ with gas boiler solution (Figure 14).

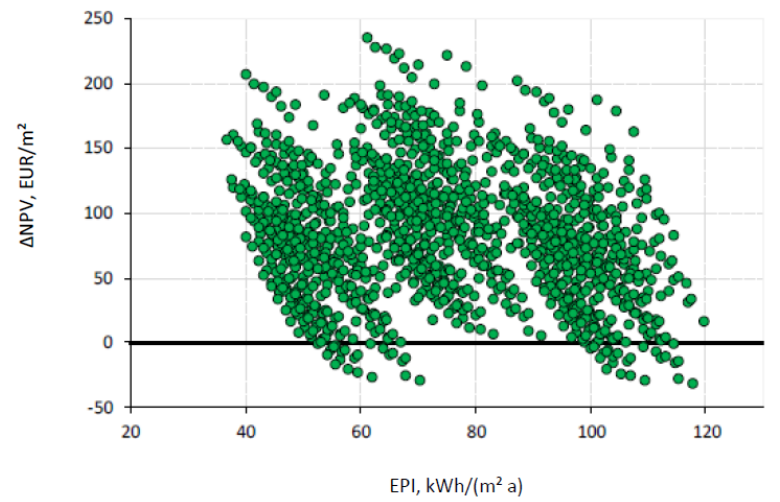

Fig. 13. Results of cost-effectiveness calculations for a detached house $\left(100 \mathrm{~m}^{2}\right)$ at the macroeconomic level.

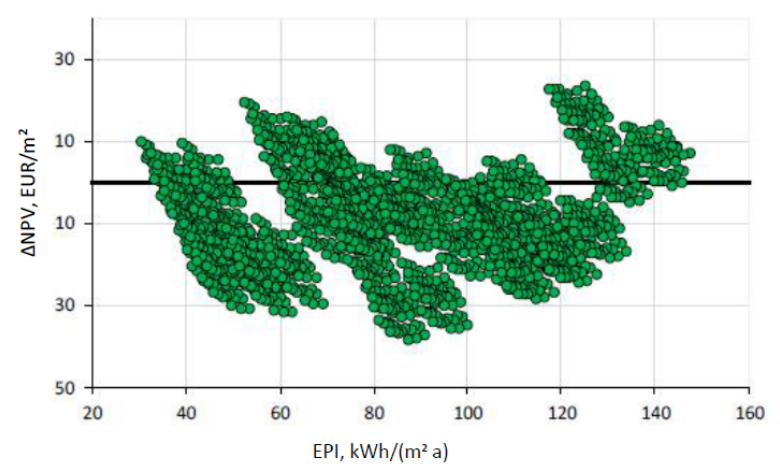

Fig. 14. Results of cost-effectiveness calculations for a detached house $\left(200 \mathrm{~m}^{2}\right)$ at the macroeconomic level.

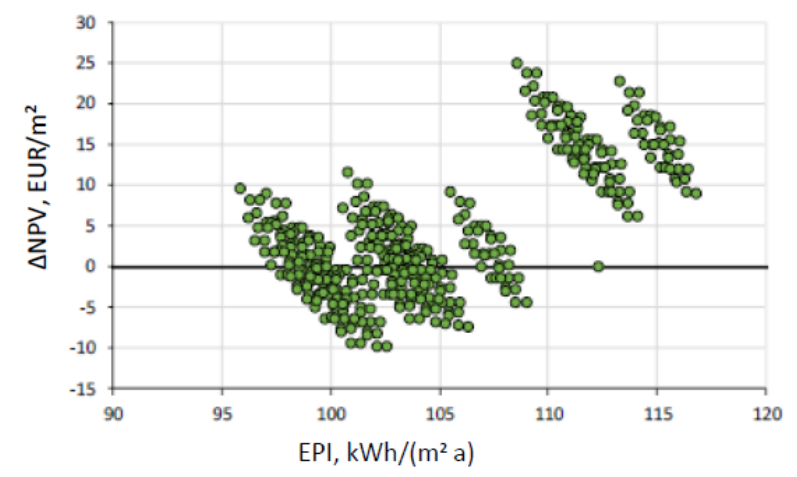

Fig. 15. Results of cost-effectiveness calculations of an apartment block at the macroeconomic level. 


\section{Discussion}

The results of the calculations for new buildings are summarised in Table 4. Compared to 2011, cost-optimal EPI has improved significantly, reaching either very close to nearly zero-energy level or even surpassing it (EPC class A). According to the results, the nearly zero-energy requirement for terraced buildings has become costoptimal, while that for the apartment blocks is only one unit away. The cost-optimal value of $200 \mathrm{~m}^{2}$ small residential buildings remained furthest away ( 7 units) from the level of the near-zero energy building. In the case of the $100 \mathrm{~m}^{2}$ small residential buildings, it is essential to consider that the nearly zero-energy requirement of 100 $\mathrm{kWh} /\left(\mathrm{m}^{2} \cdot \mathrm{a}\right)$ applies to all small residential buildings of up to $120 \mathrm{~m}^{2}$. This is why the cost-optimal energy efficiency margin is justified, because achieving energy efficiency in smaller buildings is more expensive.

Table 4. Cost-optimal levels of energy performance indicators.

\begin{tabular}{|c|c|c|c|}
\hline Building & $\begin{array}{c}\mathbf{2 0 1 1} \text { cost- } \\
\text { optimal } \\
\mathbf{k W h} /\left(\mathbf{m}^{2} \mathbf{a}\right)\end{array}$ & $\begin{array}{c}\text { Cost- } \\
\text { optimal } \\
\mathbf{k W h} /\left(\mathbf{m}^{2} \mathbf{a}\right)\end{array}$ & $\begin{array}{c}\text { Proposed } \\
\text { nearly zero- } \\
\mathbf{\text { energy }} \\
\mathbf{k W h} /\left(\mathbf{m}^{2} \mathbf{a}\right)\end{array}$ \\
\hline $\begin{array}{c}\text { Small } \\
\text { residential } \\
\text { buildings } \\
100 \mathrm{~m}^{2}\end{array}$ & - & 79 & 100 \\
\hline $\begin{array}{c}\text { Small } \\
\text { residential } \\
\text { buildings } \\
200 \mathrm{~m}^{2}\end{array}$ & 140 & 87 & 80 \\
\hline $\begin{array}{c}\text { Terraced } \\
\text { buildings }\end{array}$ & - & 71 & 80 \\
\hline $\begin{array}{c}\text { Apartment } \\
\text { buildings }\end{array}$ & 145 & 103 & 100 \\
\hline
\end{tabular}

\section{Conclusion}

The decrease in cost-optimal energy performance level in a five-year period was $\sim 38 \%$ for the detached house and $\sim 29 \%$ for the apartment building, corresponding to a shift close to nZEB level, leaping nearly two EPC classes. As two new building categories were implemented in the building regulation, cost-optimal levels were also calculated for small (heated space $\leq 100 \mathrm{~m}^{2}$ ) detached house and terraced building.

Given the significant difference between the current minimum requirements for new buildings (class C) and the cost-optimal energy efficiency levels (approximately class A), implementation of the cost-optimal requirements in two stages is justified. With a preparatory period of one year, it is possible to make a transition to class B by 31 December 2018 and to class A by 31 December 2019. It is possible to make a transition to class $C$ in the case of major renovations by 31 December 2018 with a one-year preparatory period as well.

Macroeconomic calculations were performed in Estonia for the first time, and their results in most cases overlapped with the results of financial calculations. Only in the case of the smaller residential buildings did the macroeconomic calculations demonstrate a somewhat lower cost-optimal EPI. There was no difference with regard to other buildings.

This research was supported by the Ministry of Economic Affairs and Communications, Fund KredEx, and Estonian Centre of Excellence in Zero Energy and Resource Efficient Smart Buildings and Districts, ZEBE, grant 2014-2020.4.01.150016 funded by the European Regional Development Fund.

\section{References}

1. Directive 2010/31/EU of the European Parliament and of the council of 19 May 2010 on the energy performance of buildings (recast). Official Journal of the European Union (2010).

2. Commission Delegated Regulation (EU) No 244/2012 of 16 January 2012 supplementing Directive 2010/31/EU of the European Parliament and of the Council on the energy performance of buildings by establishing a comparative methodology framework for calculating cost-optimal levels of minimum energy performance requirements for buildings and building elements. Official Journal of the European Union (2012).

3. Kurnitski, J., Saari, A., Kalamees, T., Vuolle, M., Niemelä, J., Tark, T. Cost optimal and nearly zero energy performance requirements for buildings in Estonia. Estonian Journal of Engineering 19, 183-202 (2013).

4. Kurnitski, J., Saari, A., Kalamees, T., Vuolle, M., Niemela, J., Tark, T. Cost optimal and nearly zero (nZEB) energy performance calculations for residential buildings with REHVA definition for nZEB national implementation. Energ Buildings 43, 3279-3288 (2011).

5. Pikas, E., Thalfeldt, M., Kurnitski, J., Liias, R. Extra cost analyses of two apartment buildings for achieving nearly zero and low energy buildings. Energy 84, 623633 (2015).

6. Kurnitski, J., Kuusk, K., Tark, T., Uutar, A., Kalamees, T., Pikas, E. Energy and investment intensity of integrated renovation and 2030 cost optimal savings. Energ Buildings 75, 51-59 (2014).

7. Kuusk, K., Kalamees, T. Retrofit cost-effectiveness: Estonian apartment buildings. Build Res Inf 44, 920934 (2016).

8. Estonian Regulation No 58: Methodology for calculating the energy performance of buildings. in Riigi Teataja (Ministry of Economic Affairs and Infrastructure, 2015).

9. EQUA. IDA Indoor Climate and Energy (IDA-ICE, version 4.7.1). (Equa Simulations $A B, 2017)$.

10. Kropf, S., Zweifel, G. Validation of the Building Simulation Program IDA-ICE According to CEN 13791 „Thermal Performance of Buildings - Calculation of Internal Temperatures of a Room in Summer Without Mechanical Cooling - General Criteria and Validation Procedures“. HLK Engineering (2002). 